\title{
MITOS DAN RELIGI DALAM 'GEGURITAN I DUKUH SILADRI' KARYA SASTRA KREATIF DAN DINAMIS
}

\author{
A.A. Kade Sri Yudari' ${ }^{1}$ I Gusti Agung Paramita², I Gusti Ayu Ngurah ${ }^{3}$ \\ ${ }^{123}$ Postgraduate Hindu University of Indonesia Denpasar \\ 1riyudari@unhi.ac.id, ${ }^{2}$ paramita@unhi.ac.id, ${ }^{3}$ ayungurah@unhi.ac.id
}

\begin{abstract}
This article is a small part of research report on the oral tradition of 'Nyurud di Setra' in the Klungkung-Bali Pakraman community Village Pemenang. One of the subsections reveals the relationship between myth and religion towards the traditional inherentance of Pura Dalem Suladri which is implicitly described in 'geguritan I Dukuh Siladri'. With the qualitative interpretative descriptive methods, it is understood that religion is one elements of universal culture which containts of beliefs and behavior related to supernatural power and powers. Meanwhile, myth is an important part of human life as a psychological necessity due to woory and fear of the wrath universe. In order for humans to avoid disaster, sacred and sacred stories are about objects that govern the universe are built, strengthened by sacred buildings and religious rituals. Thus, the 'geguritan I Dukuh Siladri' appears to be a creative and dynamic literary work following the reality cummunity of social life according to the time.
\end{abstract}

\section{Keywords: Myth; Religious; Creative Literary Work; Geguritan}

\begin{abstract}
Abstrak
Artikel ini merupakan sebagian kecil dari laporan hasil penelitian tentang tradisi lisan Nyurud di Setra pada masyarakat Desa Pakraman Pemenang Klungkung-Bali. Salah satu sub bagian mengungkap adanya relasi antara mitos dan religi terhadap pewarisan tradisi atas eksistensi Pura Dalem Suladri yang secara tersirat dipaparkan dalam geguritan I Dukuh Siladri. Dengan metode kualitatif, analisis deskriptif interpretatif dipahami bahwa; religi merupakan salah satu unsur kebudayaan universal yang mengandung kepercayaan dan perilaku berkaitan dengan kekuatan serta kekuasaan supernatural. Sedangkan mitos adalah bagian penting dari kehidupan manusia sebagai keniscayaan psikis akibat rasa khawatir dan ketakutan terhadap murkanya alam semesta. Agar manusia terhindar dari musibah dibangunlah cerita suci dan sacral tentang objek yang mengatur alam semesta, diperkuat dengan pendirian bangunan suci disertai ritual keagamaan. Dengan demikian, geguritan I Dukuh Siladri, tampil menjadi karya sastra kreatif dan dinamis mengikuti realitas kehidupan social masyarakat sesuai zaman.
\end{abstract}

\section{Kata Kunci: Mitos; Religi; Karya Sastra Kreatif; Geguritan}

\section{PENDAHULUAN}

Artikel ini merupakan deskripsi dari sebagian laporan hasil penelitian internal yang telah dilakukan. Secara umum penulisan artikel ini bertujuan untuk melestarikan, dan mengembangkan karya sastra tradisional sebagai warisan budaya bangsa. Dalam laporan ditemukan adanya mitos dan religi yang menjembatani keberlangsungan sebuah tradisi lisan 
'nyurud di setra' di Desa Pemenang-Klungkung. Tradisi lisan ini sedang mengalami dinamika sesuai dengan situasi dan kondisi zaman. Bahwa, mitos dan religi yang diceritakan dalam 'geguritan I Dukuh Siladri', menjadi salah satu penyebab masyarakat Desa Pemenang melakukan tradisi mengambil sisa persembahan pada setiap ritual kematian yang dikenal dengan 'ngaben'. Selain cerita suci yang menjadi saksi sejarah peradaban masa lalu, juga terdapat bangunan suci dalam bentuk Pura yang dinamai Pura Dalem Suladri. Fokus artikel ini, secara khusus untuk memahami relasi antara mitos dan religi yang ada dalam karya sastra tradisional 'geguritan I Dukuh Siladri'. Sedangkan urgensinya merupakan luaran dari laporan hasil penelitian tentang "Dinamika Tradisi Lisan 'Nyurud di Setra' pada Masyarakat Desa Pemenang Kecamatan Banjarangkan-Klungkung”.

Karya sastra tradisional di Bali khususnya geguritan ternyata masih tetap hidup dan berkembang dalam masyarakat. Karya sastra geguritan diciptakan berdasarkan ide-ide, gagasan, wujud kreatif murni pengarang yang mengandung unsur imajinasi dan dikemas sedemikian baik sehingga menjadi karya yang dapat dinikmati. Membaca karya sastra geguritan tidak seperti membaca karya prosa karena memiliki system konvensi yang cukup ketat oleh pupuh dan diikat beberapa syarat seperti halnya puisi. Pada umumnya, setiap geguritan terkandung pesan-pesan dan nilai yang begitu kuat dan mendalam untuk dijadikan cermin dalam menjalankan sebuah kehidupan. Demikian halnya dalam 'geguritan I Dukuh Siladri' selanjutnya disingkat (I DS) terdapat pesan religious yang melekat dengan nilai budaya masyarakat Bali sebagai tuntunan untuk berperilaku, berbuat, berpikir yang baik dan benar.

Dari hasil transliterasi dan transkripsi terdapat sebanyak 75 halaman naskah berbahasa Bali diterjemahkan ke dalam bahasa Indonesia. Ceritanya terdiri dari 764 bait yang dibangun oleh 8 tembang seperti; Sinom, Durma, Ginada, Dandang, Semarandana, Basur, Ginanti, dan Pangkur. Kisahnya, menceritakan dua bersaudara, seorang diantaranya yang bernama I Siladri bercita-cita dan mempersiapkan diri menjadi rokhaniawan, sehingga harus belajar pengetahuan spiritual lebih mendalam. Tujuannya untuk mencapai kehidupan yang lebih baik tidak saja untuk dirinya tetapi untuk generasi penerusnya. Setelah melalui jalan yang panjang dan berliku bertemulah dengan seorang Guru spiritual sejati bernama Mpu Dibiyaja. Sang Mpu sudah mewariskan ajarannya sebelum akhirnya meninggalkan I Siladri yang sudah diberi gelar 'Dukuh'di Pasraman (tempat menempa ilmu) untuk mencapai Moksa (bersatunya Ruh dengan Tuhan). Sebagai pewaris ajaran yang sangat luhur I Dukuh Siladri wajib menjalankan dan menyebarkan ajaran gurunya secara luas di masyarakat. Demikian secara ringkas karya dari Ida Padanda $\mathrm{Nj}$. Ngoerah yang diterjemahkan kembali oleh I Ketut Karyawan, B.A. (Karyawan, 1991).

Sebagai karya sastra tradisional, 'geguritan I DS'merupakan karya yang dinamis. Hal ini terbukti penyebarannya direpresentasikan dalam berbagai bentuk, artinya tidak hanya dalam bentuk geguritan (puisi) yang ditembangkan namun, juga dalam bentuk sastra yang lain seperti prosa, dan drama tari (dipentaskan). Demikian pula pada media cetak dan elektronik berbentuk artikel ilmiah sudah diulas berkali-kali, namun tetap saja ada sisi menariknya dari sudut pandang penulis terutama ajaran dan pesan-pesan religious, walaupun masih kental nuansa mitos dan religi yang terdapat di dalam ceritanya. Perjalanan dan perkembangan kehidupan karya sastra sangat diwarnai oleh dinamika perkembangan zaman. Suatu karya sastra tradisional selalu terkait dengan penjabaran ajaran keagamaan, dikemas sedemikian rupa ke dalam bentuk narasi yang maknanya terimplisit.

Karya sastra mengandung dua hal pokok yaitu; (1) memiliki nilai-nilai artistic tersendiri, (2) memiliki nilai-nilai spiritual kemanusiaan atau kebenaran yang universal dan hakiki (Agastia, 1980:2). Karya sastra bagaikan anak panah bagi pengarang yang dilesatkan dari busurnya untuk mencapai sasaran. Sastra adalah alat ampuh untuk menyuarakan kepedulian dan pengalaman estetiknya dalam memberikan asupan segar kepada masyarakat pembaca. Gerak kehidupan masyarakat berpengaruh terhadap perkembangan sastra baik sastra tradisional maupun sastra Indonesia modern. Perkembangan atau perubahan mencakup 
pergeseran nilai kehidupan dalam dunia sastra. Dalam kenyataan ada penilaian masyarakat mengenai segala sesuatu yang tidak modern apalagi bersifat pribumi kurang mendapat sambutan yang diharapkan. Padahal sastra tradisional seperti halnya 'geguritan I DS' mencerminkan alam pikiran, pandangan hidup, serta ekspresi rasa komunitas tertentu.

Pesan-pesan religious disampaikan dalam bentuk mitos. Mitos berasal dari bahasa Yunani muthos, yang secara harfiah diartikan sebagai cerita atau sesuatu yang dikatakan seseorang. Dalam arti yang lebih luas, mitos berarti pernyataan, sebuah cerita atau alur suatu drama. Lebih spesifik, Malinowski membedakan pengertian mitos dari legenda dan dongeng. Bagi Malinowski, legenda merupakan cerita yang diyakini seolah-olah merupakan kenyataan sejarah; sedangkan dongeng mengisahkan peristiwa-peristiwa ajaib tanpa dikaitkan dengan ritus (Dhavamony, 1995:147). Mitos dalam kaitannya dengan religi menjadi penting bukan semata-mata karena memuat hal-hal gaib atau peristiwa mengenai makhluk adikodrati, melainkan karena mitos tersebut memiliki fungsi eksistensial bagi manusia dan harus dijelaskan sesuai fungsinya (Dhavamony, 1995:150).

Fungsi mitos bagi kebudayaan primitive adalah mengungkapkan, mengangkat, dan merumuskan kepercayaan, melindungi dan memperkuat moralitas, menjamin efisiensi ritus serta memberikan peraturan-peraturan praktis untuk menuntun manusia (Malinowski, 1954: 101). Mitos, pada 'geguritan I DS' benar-benar berperan dalam religi, mengingat masih sederhananya konsep agama ketika itu di kalangan komunitas primitive. Pada saatnya mitos, mengandaikan suatu ontology dan hanya berbicara mengenai kenyataan yang sesungguhnya terjadi. Mircea Aliade, mengartikan mitos adalah sebagai kenyataan yang suci. Kesucian sebagai satu-satunya kenyataan tertinggi (dalam Dhavamony, 1995:152). Karakter mitos yang berkembang dalam 'geguritan I DS' tidak jauh dari keyakinan dan kepercayaan masyarakat Bali pada umumnya.

Sementara konsep religi yang tertuang dalam teks suci selalu memuat impian ideal yang indah-indah. Misalnya, gambaran realitas tentang indahnya 'pasraman' dalam 'geguritan I DS' dengan lingkungan hutannya yang masih asri dan menenangkan hati, di bawahnya ada aliran sungai amat jernih merupakan sumber kehidupan segala rupa binatang yang saling bersahabat serta taman bunga dan buah-buahan yang bermacam-macam (Karyana, 1991 bait.17-18). Melalui penggambaran tersebut muncul pertanyaan, bagaimana sesungguhnya relasi antara mitos dan religi dalam geguritan I Dukuh Siladri?

Subjek konstruksi mitos adalah manusia, sedangkan subjek konstruksi religi adalah kekuatan kompromistik antara Tuhan sebagai representasi wahyunya dan manusia sebagai representasi hasil penafsirannya. Manusia tidak mungkin hidup tanpa religi dan termasuk tanpa mitos, walaupun selalu mengalami kontroversi dan perubahan dari zaman ke zaman atau dari generasi ke generasi. Perubahan yang terjadi pada mitos dan religi sebagai akibat tuntutan situasional dan kondisional yang menyertainya.

Berdasarkan pemahaman tersebut, mitos yang diwarisi oleh masyarakat Desa Pemenang muncul secara tersirat dalam 'geguritan I DS' sangat berkaitan dengan religi dan peradaban masyarakat Bali Kuno secara umum sebagai masyarakat agraris. Artinya, mitos yang diimplementasikan menjadi tradisi 'nyurud di setra' tidak hanya milik masyarakat Desa Pemenang (Klungkung), tetapi merupakan panduan dasar dalam mengatasi permasalahan kehidupan di Bali pada zaman itu. Dengan demikian, mitos pada masyarakat agraris yang sama sekali belum memasuki tahapan masyarakat industry, bukanlah mitos yang ada pada masyarakat post-industry apalagi post-modern (Arkoun, 1999:113). Keadaan ini pula yang membuat Arkoun menjadi optimis terhadap nilai dan fungsi mitos itu sendiri.

\section{METODE}

Artikel ini focus mengkaji 'geguritan I DS' melalui pendekatan mitopoik. Bahwa, dalam menciptakan karya seni para seniman memanfaatkan ketaksadaran masa lampau terdiri atas ketaksadaran personal yang diterima dalam kehidupan sekarang (ontogenesis) dan impersonal 
yang diterima melalui nenek moyang (filogenesis). Karya sastra memang bukan mitos, tetapi bentuk estetis karya sastra adalah manifestasi dari mitos (Ratna, 2010:67).

Secara teoretis, mitos menurut pandangan Arkoun senantiasa mengidealkan adanya pembaruan sesuai tingkat perkembangan zamannya. Sekali saja kehilangan daya aktualnya maka mitos tidak memiliki kemampuan untuk membangkitkan nilai vitalitas masyarakatnya. Menurut Arkoun, mitos berperan sebagaimana layaknya fungsi religi, tetapi tidak menggantikannya. Hal tersebut dikarenakan mitos adalah impian dan pesan kebajikan universal yang berperan sebagai sumber nilai dan dapat dijadikan pedoman dalam kehidupan.

Mitos memiliki pemahaman yang sangat berbeda dengan mitologi karena merupakan dua kata yang memiliki perbedaan mendasar. Perbedaan tersebut tidak hanya pada jenisnya, namun juga pada tingkatannya. Menurut Arkoun, ketika mitos telah runtuh dan kehilangan daya mitisnya maka mitos itupun berubah menjadi mitologi yang tidak memiliki nilai, sekalipun tetap tertanam kuat dalam kesadaran populisme kelompok masyarakat. Jadi menurut Arkoun, mitos memiliki makna positif karena dapat mengisi tekad dalam cita-cita dan mendorong ke arah kebangkitan realisasi diri di bumi ini.

Sementara itu, mitologi hanya melemahkan tekad dan menyerukan sikap santai, puas bahkan menyerah terhadap dekapan fanatisme yang sakit dan tidur di atas sejarah. Mitos yang telah usang dapat melahirkan mitologi. Dalam hubungannya dengan konteks modern, merupakan penggambaran keilmuan bagi realitas yang telah menggantikan posisi mitos, sementara ideology dan religi dalam arti negative telah menggantikan posisi mitologi (Arkoun, 1999:114). Semangat nilai konstruksi mitos tidak terlepas dari latar sosio-kultural pengkonstruk mitos itu sendiri, tergantung kapan, dan di mana mitos tersebut di konstruksi. Dengan demikian, dapat dipahami bahwa karakteristik mitos yang berkembang pada masyarakat Desa Pemenang, tentu tidak jauh dari peradaban dan kepercayaan Bali kuno. Demikian juga mitos yang berkembang di tempat-tempat lainnya tidak terlepas dari karakter dasar kondisi lokalitasnya.

Metode yang digunakan dalam menganalisis data adalah metode deskriptif-interpretatif. Pada dasarnya medium pesan adalah bahasa, baik lisan maupun tulisan. Karya sastra perlu ditafsir, sebab di satu pihak karya sastra terdiri atas bahasa, di pihak lain di dalam bahasa terdapat banyak makna yang tersembunyi atau sengaja disembunyikan. Jika dikaitkan dengan fungsi utama interpretasi sebagai metode untuk memahami religi, oleh karena itu mestinya dipandang tepat dalam memahami karya sastra. Dalam penjabaran dan deskripsi data, penulis menggunakan metode kualitatif dengan lebih banyak memberikan perhatian pada makna dan pesan sesuai hakikat objek. Hal ini dilakukan karena penelitian bersifat alamiah, dapat terjadi dalam konteks social budaya masing-masing daerah. Asal mula religi adalah firman Tuhan, asal mula sastra adalah kata-kata pengarang. Perbedaannya, religi merupakan kebenaran keyakinan, sedangkan sastra merupakan kebenaran imajinasi, tetapi keduanya berdasarkan atas bahasa lisan maupun tulisan.

Metode deskriptif-interpretatif tidak mencari makna yang benar, melainkan makna yang paling optimal. Dalam menginterpretasi, untuk menghindarkan ketidakterbatasan proses interpretasi digunakan gerak spiral. Penafsiran terjadi karena setiap subjek memandang objek melakukan horizon dan paradigma yang berbeda-beda. Keragaman pandangan dapat menimbulkan kekayaan makna dalam kehidupan manusia, dan menambah kualitas estetika serta logika (Ratna, 2010:46).

\section{HASIL DAN PEMBAHASAN}

\section{Dimensi Mitis Dalam Geguritan I Dukuh Siladri.}

Dalam ajaran Hindu konsep Surga dan Neraka itu ada, tetapi bukan menjadi tujuan akhir dari manusia karena bagi orang yang beragama Hindu tujuan akhir bukan masuk surga tetapi moksa atau bersatunya jiwa (Atman) dengan Sang Pencipta (Brahman) sesuai karmanya. Kitab Bhagavad Gita (BG. IX.21) menyebutkan: "Mereka menikmati Surga yang luas, dan ketika 
buah dari karma baik habis, mereka memasuki dunia yang tidak abadi ini. Demikianlah, mereka yang mengikuti aturan Veda, mendambakan hasil dari perbuatan mereka, memperoleh lingkaran hidup dan mati”.

Surga dan Neraka adalah pesinggahan sementara. Surga dan Neraka hanya dapat digambarkan sebagai suatu kondisi, apabila dalam kondisi senang, bahagia, itu adalah Surga dan sebaliknya Neraka, apabila kita dalam kondisi sedih dan menderita. Bagi atman yang ketika hidup di dunia banyak berbuat subha karma (berbuat baik) dari pada asubha karma (berbuat tidak baik) mereka disinggahkan sementara di Surga. Dan sebaliknya, bagi atman yang ketika hidup banyak berbuat asubha karma dari pada subha karma mereka disinggahkan di Neraka. Jadi, semua tergantung hasil karma mereka masing-masing, akibat ketidakmampuan dalam mempertahankan kesucian sang Atman sebagai bagian dari Brahman Yang Maha Suci. Setelah menikmati Surga atau Neraka, jiwa (Atman) bisa kembali lahir ke dunia untuk melanjutkan evolusi sampai akhirnya mencapai Moksa.

Sedangkan, Neraka dalam pandangan Hindu digambarkan sebagai suatu tempat dan kondisi yang terletak jauh di dalam bumi. Adalah tempat penyiksaan yang sangat mengerikan berbentuk kawahapi yang panasnya beribu kali lipat dari panas api di dunia. Ruh-ruh yang banyak melakukan dosa di dunia bisa mengalami penyiksaan, ditusuk dengan tombak dan dipukul dengan palu godam. Dalam ajaran Hindu, beberapa sloka yang menjelaskan konsep Neraka sangat sedikit, karena Hindu mengakui terjadinya Reinkarnasi atau proses kelahiran kembali dan konsep Moksa. Sehingga Neraka dikatakan sebagai balasan yang diterima pada saat reinkarnasi. Maka di dalamnya kita diberikan dua pilihan yang berdasarkan pada perbuatan semasa hidup terdahulu, yakni reinkarnasi Surga atau reinkarnasi Neraka.

Pemikiran dasar mengenai mitos hampir sama di dunia walaupun berada di bawah kondisi social serta budaya yang berbeda. Gejala alam dan gejala manusia dapat ditafsirkan secara mitis dan keduanya memang memerlukan interpretasi mitis. Karenanya, membicarakan mitos harus meyakini bahwa mitos memiliki arti yang dapat dipahami. Dalam pemikiran mitis primitive terdapat keyakinan bahwa manusia untuk mencapai tujuan yang dikehendaki harus bekerjasama dengan alam serta kekuatan-kekuatan Ilahi.

Hindu juga mengajarkan, kehidupan ini adalah suatu perjalanan yang saling berhubungan dan berlangsung terus-menerus. Pada konsep Tuhan Maha Pengampun, Hindu menjelaskan setiap manusia selalu diberikan kesempatan untuk memperbaiki dirinya dalam beberapa kali masa kehidupan untuk kemudian mencapai tujuan tertinggi yakni, Moksa. Penggambaran tentang Surga menurut Srimad Bhagavatam, menguraikan bahwa tempat-tempat surgawi merupakan tempat di mana para makhluk hidup menghabiskan dan menggunakan kegiatankegiatan salehnya yang terdahulu. Tempat-tempat surgawi ditemukan di tiga tempat yaitu; di atas bumi, planet-planet surga bawah dan planet-planet surga atas. Hanya orang yang saleh dapat memasuki 'surga atas'. Orang-orang yang hanya mengalami atmosfer surga yang lebih rendah dapat ditemukan di bumi atau 'planet-planet bawah'.

Di dalam Srimad Bhagavatam (V.17.12) disebutkan bahwa di Surga Atas dan di Bumi sebelum munculnya zaman Kali, ribuan tahun yang lalu para penduduk hidup selama sepuluh ribu tahun dan semuanya mirip Dewa.

"Mereka memiliki kekuatan sepuluh ribu gajah dan badan sekuat halilintar. Masa muda dalam kehidupan mereka sangat menyenangkan, baik pria dan wanita menikmati kesenangan dalam jangka waktu lama. Setelah sekian lama merasakan nikmatnya hidup, dan sekitar setahun masa kehidupan masih tersisa, sang istri pun mendapatkan seorang anak".

Demikianlah standar kesenangan para penduduk Surga, disamakan dengan manusia yang hidup pada zaman Treta Yuga (ketika tidak ada gangguan). Sebaliknya, penggambaran tentang Neraka juga ada di seluruh literature Veda khususnya dalam kitab-kitab Purana ada uraian mengenai planet-planet Neraka seperti dalam Bhagavatam (VI.1.42) disebutkan; Planet-planet Neraka merupakan tujuan bagi mereka yang mengalami penderitaan sebagai pahala (hasil) atas segala kegiatan mereka yang jahat dan keji. Tentu saja jika orang bisa memilih sendiri apakah 
mereka mau pergi ke Neraka atau tidak, maka tidak satupun yang memilih pergi kesana. Namun, sayangnya kita tidak dapat memilih, hal ini tergantung pada otoritas-otoritas yang lebih tinggi yang menyaksikan dan menghakimi segala tindakan kita.

Mitos 'Surga' dan 'Neraka' yang dikonstruksi di tengah-tengah kehidupan masyarakat seringkali menampakkan nilai-nilai religious-mistis. Seperti halnya dalam 'geguritan I DS' (bait 29-32) disebutkan bahwa, pilihan surga maupun neraka dalam kehidupan tergantung dari perbuatan yang merupakan oleh-oleh orang mati. Jika berbuat baik maka tempatnya adalah surga dan sebaliknya bila tidak baik tempatnya di neraka. Hal itu terjadi berdasarkan kombinasi karma yang telah dikumpulkan seseorang sesuai dengan sifat-sifat alam (guna) tertentu yang dimilikinya. Seringkali terjadi kesalahpahaman tentang 'surga dan neraka', bahwa menjalani sebuah kehidupan yang religious untuk mencapai surga adalah tujuan tertinggi. Tetapi untuk meluruskannya harus memiliki uraian tentang 'surga dan neraka' secara mendetail yang dapat ditemukan dalam literature Veda. Kitab Veda menekankan bahwa, "Matahari, api, akasa, udara, para Dewa, bulan, senja, malam, siang, arah mata angin, air, tanah, dan Ruh Yang Utama (Paramatma) semuanya menyaksikan segala kegiatan makhluk hidup (sebagai saksi). Karenanya makhluk hidup tidak dapat pergi ke manapun, di mana tidak ada yang melihat sesutau yang telah dilakukannya.

Dalam 'geguritan I DS' ada beberapa bait yang menyebutkan penggambaran tentang mitos Surga dan Neraka yakni pada bait. 29-32 sebagai berikut.

"Di gumine twara ada melah setata, jele melah tuah panggih, apa tong dadi belasang, lingling Sarasamuscaya, telu lokane sujati, nista madia utama, pada len ditu kapanggih" (bait.29).

Terjemahannya: Di dunia ini tidak ada hal yang baik selalu, buruk baik memang berdampingan, memang tidak bisa dipisahkan, di dalam Sarasamuscaya dikatakan, ada tiga tempat sejati, nista - madya - utama, terlihat sekali ada perbedaannya.

"Swargaloka martiloka nrakaloka, ento loka telu jati, ring swarga magenah, abesik ditu pagehang, suka setata kepanggih, ring nrakaloka magenah, masih abesik tepukin" (bait.30).

Terjemahannya: Swargaloka - martiloka - nerakaloka, itulah tiga tempat sejati, sorga merupakan salah satu tempat, sekali disana teguhkan hati, suka-cita selalu ditemukan, di nrakaloka merupakan tempat, dimana hanya satu ditemukan.

"Sakit ati engkak-engkak setata, krana madan nraka gumi, ring martialoka, seenune ring jagat, dadwa setata kapanggih, suka nraka tan simpang, idupe matimpal mati" (bait.31). Terjemahannya: Sakit hati dan penuh penderitaan, karena itu bernama neraka bumi, sedangkan di martialoka, semasih di bumi, dua hal selalu ditemukan, suka dan neraka tidak terpisahkan, hidup selalu diiringi mati.

"Subba mati lokane dadwa ungsiang, salah tunggal tuara pelih, swargaloka-nrakaloka, nuut saparikrama, ento tuah bekelang mati, ulah ala nemu nraka, ulah ayu manggih swargi" (bait.32).

Terjemahannya: Sesudah meninggal ada dua tempat yang dituju, salah satu yang dipilih, swargaloka atau nrakaloka, semua tergantung perbuatan, itulah oleh-oleh orang mati, bertingkah buruk menemukan neraka, bertingkah baik menemukan Surga.

Dalam pandangan Hindu, terutama yang berlandaskan kitab-kitab Purana, Surga dan Neraka merupakan kondisi yang dialami oleh ruh ketika terjadi proses kematian. Artinya, Surga dan Neraka dapat ditemukan setelah melewati jembatan yang bernama kematian (Titib, 2003:94). Kehidupan di Surga atau Neraka yang dijalani tergantung karma, bila lebih banyak berbuat buruk berarti waktu lebih banyak dihabiskan di Neraka dan sebaliknya. Jadi, Surga maupun Neraka merupakan ganjaran, karenanya tidak ada Surga dan Neraka abadi. Keabadian dalam Hindu adalah Moksa. 


\section{Dimensi Religi dalam Geguritan I Dukuh Siladri.}

Religi adalah kebenaran yang bersumber pada Tuhan. Interpretasi puitik seorang penyair terhadap religi merupakan usaha kreatif dengan latar belakang pengalaman insaniahnya. Untuk mencoba menelusuri kebenaran religi tersebut dalam hidupnya sebagai manusia, diungkaplah melalui puisi. Puisi-puisi yang bertemakan religious sesungguhnya mengajak pembaca merenungi kekuasaan Tuhan, sehingga manusia lebih menyadari keterbatasannya.

Itulah sebabnya, para bijak yang memahami kehidupan sebagai siklus, tidak pernah berduka atau bersedih atas kematian. Seseorang yang meninggal sesungguhnya sedang menjalani proses perubahan wujud. Dalam Bhagavad-Gita (BG.II.11-13) dijelaskan agar kita tidak bersedih terhadap orang mati.

"Kau bergelisah hati dan menangisi mereka yang tidak perlu ditangisi. Kata-katamu seolah penuh kebijaksanaan, padahal para bijak tidak pernah bersedih hati bagi mereka yang masih hidup, maupun yang sudah mati" (BG.II.11).

Mereka yang tidak memahami siklus kelahiran dan kematian selalu menangisi orang yang mati, apalagi jika orang itu ada hubungan persaudaraan dengannya, atau orang yang dicintainya. Dalam beberapa tradisi dialog tentang kematian pun dianggap tabu. Kematian dikaitkan dengan kemalangan, sedang kehidupan adalah keberuntungan. Banyak tradisi yang mengganggap kematian sebagai titik akhir dari kehidupan yang menyebabkan duka. Tidak demikian halnya dengan para bijak yang memahami kematian sebagai bagian proses dari siklus kehidupan, mati-lahir berputar terus ibarat roda kehidupan.

"Tidak pernah ada masa di mana Aku, engkau, atau para pemimpin yang sedang kau hadapi saat ini, tidak ada, tidak eksis. Dan tidak pula ada masa di mana kita semua tidak akan ada, tidak eksis lagi” (BG.II.12).

Dalam keadaan pralaya atau yang disebut kiamat total pun, ada sesuatu Yang Tak Terjelaskan yang tetap ada. Krisna, menjelaskan hal itu dalam percakapan berikut. Siklus atau cycle bersifat circle, bulatan. Jika kehidupan dipahami sebagai garis datar, horizontal atau vertical, maka kita tidak bisa tidak bersedih atas kematian orang yang kita sayangi, karena kehidupan sudah berlalu. Tidak ada kemungkinan bagi kita untuk bertemu dengannya lagi.

"Masa kecil, dewasa, pun masa tua adalah 'kejadian-kejadian'yang terjadi pada badan yang dihuni Jiwa. Kemudian setelah badan lama ditinggalkan, jiwa memperoleh badan baru. Para bijak tidak pernah meragukan hal ini atau terbingungkan olehnya" (BG. II.13).

Badan kecil kita mati untuk menjadi remaja. Badan remaja mati setiap hari untuk menjadi dewasa. Dan badan dewasa pun menjalani kematian dari detik ke detik untuk menjadi tua, kemudian terjadilah proses pendaur-ulangan, dan jiwa penghuni badan saat ini meraih badan baru. Demikian, para bijak yang memahami proses ini tidak pernah berduka.

Dalam 'geguritan I DS'beberapa bait isinya merupakan nasihat Empu Dibiyaja kepada I Dukuh Siladri tentang kematian yang tidak perlu ditangisi ada pada bait.25-26 berikut.

"Lintang welas Empu Dibiyaja mirengang, raris ide mituturin, "Duh Siladri purnayang, da sanget manyelselang, baan somah cai mati, mula tuah janjinya, tuara ada dadi kelidin" (bait.25).

Terjemahannya: Empu Dibiyaja sangat kasihan mendengar, lalu beliau menasehati, "Duh Siladri lupakan, jangan sekali menyesal, oleh karena istrimu telah meninggal, sudah kodratnya, tidak bisa kita hindari.

"Twinnya kene tingkahe numadi jadma, idupe pamragat mati, yadin tingkah masomah, pamragatnya dadi belas, tresna demene nyakitin, ento ngawe buyar, patut idepe magedi" (bait.26).

Terjemahannya: Memang seperti lingkaran hidup menjadi manusia, hidup ini menunggu mati, apapun perilaku saat bersuami-istri, pada akhirnya pasti berpisah, cinta kasih dan suka cita memang menyakitkan, itulah yang membuat kebingungan, sudah sepantasnya pikiran itu dikendalikan. 
Manusia tidak bisa lepas dari hukum alam yang mengaturnya seperti lahir, hidup, mati adalah merupakan kodrat. Kematian merupakan suatu hal yang pasti dalam kehidupan dan jika suatu ketika menimpa keluarga dekat, sahabat karib belum bisa sepenuhnya diterima sebagai hal yang wajar sehingga kematian menjadi sesuatu hal yang sangat menakutkan. Dalam Bhagavad- Gita disebutkan, segala masalah dan musibah tidak pernah diciptakan oleh Sang Hyang Widhi (Tuhan). Demikian juga dengan kelahiran dan kematian, semua karena ulah manusia yang tidak bisa berdamai dengan alam. Apabila manusia menerima kelahiran maka harus siap menerima kematian, demikian sebaliknya seperti siklus.

"Jatasya hi druvo mrtyur, ahruvam janma mrtasya ca, tasmad apraiharye rthe, na tvam socitum arhasi” (BG. II.27).

Artinya: sesungguhnya setiap yang lahir, kematian adalah pasti, demikian pula setiap yang mati kelahiran adalah pasti, dan hal ini tak terelakkan, karena itu tidak ada alasan engkau merasa menyesal.

Dalam 'geguritan I DS' (bait 23-24) disebutkan.

"Yadin idup tan urung mepes yeh mata, idupe waluye mati, nanging beli ngrasa pisan, tuah mawak leteh jagat, mabudi mangalih suci, joh para nyidayang, nyemak tendas lima daki" (bait.23).

Terjemahannya: Apabila dalam kehidupan terdahulu selalu meneteskan air mata, hidup ini pun terasa seperti mati, akan tetapi kakak sangat percaya diri, merasa diriku sudah mengotori bumi, berkeinginan yang tinggi untuk mencapai kesucian, siapa tahu bisa tercapai, ibarat menggaruk kepala dengan tangan yang kotor.

"Buka jani yan nyai enu pitresna, alih beli ajak mati, nanging da makeloang, panak nyai barengang, ngadung bareng ajak sakit, apang da belas, yadin ngalih awecil" (bait.24).

Terjemahannya: Dalam keadaan seperti sekarang jikalau kamu masih cinta, cari kakak dan ajaklah mati, tetapi jangan terlalu lama, anakmu juga diikutkan, mumpung bersama kita ajak menderita, supaya jangan terpisah, walaupun akhirnya menemukan sengsara.

Kesenangan duniawi yang menyebabkan orang betah dan selalu ingin berada dalam wujud badan jasmaninya. Saat kematian datang, seseorang merasa sedih dan takut, karena meninggalkan kebiasaan-kebiasaan yang telah dijalaninya bertahun-tahun, terlebih kebiasaan itu merupakan hal yang menyenangkan. Maka perlu disadari bahwa sang diri bukan hanya sekedar badan, karena ada jiwa yang perlu mendapat pencerahan dengan pengetahuan rohani. Sedangkan kematian dalam pemikiran tradisional, tidak pernah dipandang sebagai fenomena alami, melainkan suatu kebetulan yang terjadi akibat terkena sihir atau pengaruh berbagai permusuhan pribadi. Dengan demikian, anggapan terhadap kematian secara kodrati adalah hal yang pasti dialami manusia, tetapi dianggap tidak benar dari sudut pandang pemikiran mitis maupun religious. Demikian halnya, dalam kisah IDS kesadaran terhadap sang diri rupanya belum tercerahkan, yang membuat rasa sedih, kecewa berkepanjangan atas kematian istrinya.

\section{Relasi Mitos dan Religi dalam Geguritan I Dukuh Siladri.}

Hubungan sastra dengan religi seringkali terselubung dan tidak ada alat untuk membuka atau mengurai unsur-unsur yang tersembunyi di dalamnya. Karya sastra dipandang religious sebab di dalamnya mengandung pengalaman religious. Namun, dalam kenyataannya pengalaman religious tidak pernah bisa ditunjuk secara langsung karena bukan pengalaman indrawi melainkan bersifat abstrak.

Sementara itu bahasa memiliki keterbatasan hanya dapat mengungkap yang menjadi sumber realitas. Pembaca sering mengasumsikan bahwa moralitas di dalamnya selaras dengan moral pengarang. Rumusan Einstein, tentang relativitas menyebutkan materi adalah energy dalam bentuk lain yang tidak pernah hilang, selalu ada hanya berubah bentuk. Jika kita memperhatikan alam, lingkungan sekitar atau memahami hukum-hukum kebendaan sebagaimana terungkap dalam ilmu fisika, maka pasti memahami pula bahwa sesungguhnya kematian adalah mitos. Perubahan adalah yang abadi, materi hanya berubah bentuk saja. 
Dalam konteks cakupan mitos dan religi konsep mengenai alam dan kehidupan manusia tidak terlepas dari makna rasional. Lapisan di mana mitos bergerak bukanlah lapisan pemikiran, melainkan perasaan. Kaitannya dengan problema kehidupan religi misalnya, dalam 'geguritan I DS' layak menjadi model. Banyak mengilhami masyarakat tentang pemahaman kematian yang sudah pasti dan ritual yang wajib dijalankan. Geguritan ini membangun oposisi binair antara 'hidup dan mati', antara sikap keagamaan dan sikap kemanusiaan. Melalui oposisi binair dituntun untuk memilih mana yang lebih penting dan harus diambil. Apakah memilih sikap sesuai dengan hukum agama dengan konsekuensi menghancurkan kebahagiaan manusia, atau berpihak pada sikap kemanusiaan dengan konsekuensi menanggung dosa menurut hukum agama. Tampaknya I Dukuh Siladri memilih melaksanakan kewajiban hukum-hukum keagamaan, seperti yang disebutkan dalam 'geguritan IDS' bait. 44-46 berikut.

"Nah purnayang keme jua cai majalan, jani sawene enjutin, pangentas pangesengan, duur pemuhunan jemak, suba ada uli nguni, Siladri ngiringang, nyembah raris mapamit" (bai. 44).

Terjemahannya: Nah selanjutnya selesaikan dan berjalanlah kesana, kemudian mayat dibakar, siratkan tirta pengentas pada pembakaran, ambilah di atas tempat pembakaran, tradisi ini sudah ada sejak dulu, Siladri menuruti nasihat Sang Empu, lalu menyembah dan permisi.

"Tuun kelod ada pamuunan rata, babataran bata mukir, ditu sawene kejang, puput sampun mahentas, sawene raris kabasmi, api dumilah, saksama sampun basmi" (bait. 45).

Terjemahannya: Menurun disebelah selatan ada tempat pembakaran rata, dialasi batubata yang diukir, taruhlah mayatnya disana, setelah selesai diberi tirta pengentas, mayat lalu dibakar, bila api terlihat sudah menyala, selesai sudah ritual pembakaran mayat.

"Tur kakirim abune menekan kaja, yeh mumbul di duur bukit, suluk membah nuunang, abune ditu kakutang, anyud manerus ke pasih, lingsir Hyang Surya, sayonge manglikub" (bait.46).

Terjemahannya: Selanjutnya kirim abunya naik menuju arah utara, dimana terdapat mata air di atas bukit, aliran airnya menurun mengalir deras, buanglah abunya disana, sampai hanyut menuju ke laut, matahari sudah menunjukkan sore hari, embun sore hari menyelimuti bukit.

Pada zaman Bali Kuno umumnya jenazah yang meninggal dunia mayatnya akan dikubur namun, sejak zaman Bali Tengahan sudah mulai melaksanakan tradisi pembakaran jenazah bagi yang meninggal dunia dan dikenal dengan istilah 'ngaben' yaitu ritual khusus yang perlu dilakukan untuk mengantar kepergian jenazah selama-lamanya. Kepercayaan masyarakat Hindu di Bali, terhadap upacara 'ngaben' memiliki 3 tujuan utama sebagai berikut. 1) sebagai bentuk pelepasan ruh atau Sang Atman dari belenggu duniawi; 2) pelepasan itu menjadi sarana untuk mempermudah ruh untuk bersatu dengan Tuhan; 3) mengembalikan segala unsur Panca Maha Bhuta yakni, lima unsur yang membangun badan kasar manusia seperti unsur padat berupa tulang, daging, dan kuku sebagai (pertiwi), unsur cair (apah), unsur udara (bayu), unsur panas (teja), unsur ether (akasa) yang keberadaannya digambarkan rongga pada tubuh manusia. Demikianlah, tujuan terakhir dari pelaksaan ritual'ngaben'sebagai symbol atau tanda bahwa pihak keluarga yang ditinggalkan telah ikhlas atas kepergian jenazah.

\section{SIMPULAN}

Mitos dan religi merupakan gejala kebudayaan manusia yang tidak mudah dianalisis secara logis. Dalam hal ini penting melibatkan kepercayaan dan imajinasi mitis, sebab tanpa adanya kepercayaan bahwa hal itu real (nyata) maka mitos dapat kehilangan dasar-dasarnya. Mitos tidak membicarakan hal-hal yang bersifat konkret karena mitos adalah hasil dari emosi, dan latar belakang emosional tersebut dapat mengakibatkan berbagai perbedaan dalam pengalaman empiris. Lapisan di mana mitos bergerak bukan lapisan pemikiran melainkan 
perasaan. Sedangkan religi selalu berhubungan dan dipahami melalui unsur-unsur mitis. Religi lahir dari kekuatan-kekuatan moral tetapi tidak memiliki kekuatan untuk mengembangkan kecenderungan menekan dan menghilangkan naluri terdalam manusia. Alam tidak dapat memberikan sesuatu kepada manusia yang tidak melakukan aktivitas. Pesan-pesan religious yang dominan terdapat dalam 'geguritan IDS' akan menjadi pengingat dalam hidup ini bahwa, menjaga badan itu sangat penting, tetapi jangan berlebihan harus seimbang antara kebutuhan jasmani dan rohani. Manusia tidak mampu mempertahankan badan jasmani dan pasti kembali ke asalnya yaitu Panca Maha Bhuta. Pemujaan terhadap nenek moyang dalam Hindu merupakan sifat menyeluruh yang dapat menandai serta menentukan jalannya kehidupan social dan religious. Teks 'geguritan I DS' menyimpan berbagai ajaran religious, termuat dalam baitbait pada pupuh yang membentuknya. Berbagai ajaran dan keyakinan Hindu seperti Surga, Neraka dan Kematian dapat memberikan gambaran untuk dijadikan cermin dan landasan dalam mengatasi permasalahan hidup. Relasi antara mitos dan religi yang terdapat di dalamnya tidak dapat dipisahkan. Dengan demikian, sebagai penutup dapat disimpulkan bahwa 'geguritan I DS'merupakan karya sastra kreatif dan dinamis. Teks 'geguritan I DS'mengandung berbagai pesan bijak dalam bentuk mitos yang bermakna religi dan berguna untuk mengatasi kebuntuan berpikir. Oleh sebab itu, mumpung masih diberi kesempatan hidup, mari perbaiki kualitas karma dengan selalu berbuat yang baik, insyaf diri, berserah diri kepada Sang Hyang Widhi Wasa (Tuhan Yang Maha Esa), merupakan kebutuhan utama manusia sebagai jiwa atau ruh.

\section{DAFTAR PUSTAKA}

Agastia, IBG. (1980). Geguritan Sebuah Bentuk Karya sastra Bali, paper yang dibaakan pada Saresehan Sastra Daerah Pesta Kesenian Bali ke-2 di Denpasar.

Arkoun, Muhammed. (1999). Membongkar Wacana Hegemonik dalam Islam dan PostModernisme. Diterjemahkan oleh Hasyim Shaleh. Surabaya: al Fikr.

Bhaktivedanta Swami Prabhupada, Sri Srimad A.C. (2006). Bhagavad Gita Menurut Aslinya. Jakarta: CV. Hanuman Sakti.

Cohan, Parcy S. (1969). Theories of Myth, dalam Man, The Journal of The Royal Anthropological Institute, Vol. 4 No. 3 September.

Djamhari. (1988). Agama dalam Perspektif Sosiologi. Jakarta: Departemen Pendidikan dan Kebudayaan Dirjen Dikti, Proyek Pengembangan Lembaga Pendidikan Tenaga Kependidikan.

Dhavamony, Mariasusai. (1995). Fenomenologi Agama. Yogyakarta: IKAPI.

Hayat, Muhammad. (2003). Bertahannya Tradisi Tengger dalam Masyarakat Yang Sedang Berubah, dalam Nuruddin dkk. Agama Tradisional: Potret Kearifan Hidup Masyarakat Samin dan Tengger. Yogyakarta: LkiS.

Karyawan, I Ketut. (1991). Geguritan I Dukuh Siladri. Jakarta: Departemen Pendidikan dan Kebudayaan.

Kuntowijoyo. (2002). Selamat Tinggal Mitos Selamat Datang Realitas. Bbandung: Mizan.

Maharaj, Suami. (ed. Ngakan Putu Putra). (2013). Pesan Abadi Veda. Bandung: Media Hindu.

Malinowski, Bronislow. (1954). Magic, Science and Religion. New York: Daubleday Anchor Book.

Ratna, Nyoman Kutha. (2010). Teori, Metode, dan Teknik Penelitian Sastra. Yogyakarta: Pustaka Pelajar.

Titib, I Made. (2003). Purana: Sumber Ajaran Hindu Komprehensif. Surabaya: Paramita.

Titib, I Made. (2006). Persepsi Umat Hindu Bali Terhadap Svarga, Naraka, dan Moksa dalam Svargarohanaparva. Surabaya: Paramita. 